\title{
Infeksi Neonatal Akibat Air Ketuban Keruh
}

\author{
M. Sholeh Kosim \\ Bagian Ilmu Kesehatan Anak Fakultas Kedokteran Universitas Diponegoro/RSUP Dr. Kariadi, \\ Semarang
}

\begin{abstract}
Infeksi neonatal masih merupakan masalah di bidang pelayanan Perinatologi dengan angka morbiditas dan mortalitas yang cukup tinggi dengan berbagai latar belakang penyebab. Air ketuban keruh bercampur mekonium (selanjutnya disebut AKK) dapat menyebabkan sindrom aspirasi mekonium (SAM) yang mengakibatkan asfiksia neonatorum yang selanjutnya dapat berkembang menjadi infeksi neonatal. Diagnosis berdasarkan atas penemuan pemeriksaan radiologis. Penyebab SAM belum jelas mungkin terjadi intra uterin atau segera sesudah lahir akibat hipoksia janin kronik dan asidosis serta kejadian kronik intra uterin. Faktor risiko SAM adalah skor Apgar <5 pada menit ke lima, mekonium kental, denyut jantung yang tidak teratur atau tidak jelas, dan berat lahir. Diagnosis infeksi neonatal sulit, didasarkan atas anamnesis, pemeriksaan klinis, dan pemeriksaan penunjang. Banyak panduan atau sistem skor untuk menegakkan diagnosis infeksi neonatal. Salah satu panduan yang dapat digunakan untuk mendiagnosis infeksi neonatal adalah panduan WHO yang sudah diadaptasi di Indonesia. Diagnosis pasti ditegakkan dengan biakan darah, cairan serebrospinal, urin, dan infeksi lokal. Petanda diagnostik sangat berguna sebagai indikator sepsis neonatal karena dapat meningkatkan sensitivitas dan ketelitian diagnosis serta berguna untuk memberikan menghentikan secara dini terapi antibiotik. Namun tidak ada satupun uji diagnostik terbaru tunggal yang cukup sensitif dan spesifik. (Sari Pediatri 2009;11(3):212-8).
\end{abstract}

Kata kunci: infeksi, neonatus, air ketuban, mekonium

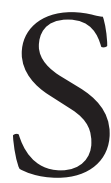
urvei Demografi dan Kesehatan Indonesia (SDKI) tahun 2007 mendapatkan angka kematian bayi (AKB) di Indonesia, 35 bayi per 1000 kelahiran hidup. Bila dirincikan 157.000 bayi meninggal per tahun atau 430 bayi per hari. Beberapa penyebab kematian bayi disebabkan berat badan lahir rendah, asfiksia, tetanus, infeksi, dan masalah pemberian minum. ${ }^{1}$

\footnotetext{
Alamat korespondensi

Dr. M. Sholeh Kosim, SpA(K). Sub Bagian Perinatologi Bagian IKA FK UNDIP/RSUP Dr.Kariadi Semarang Email : mskosim@indosat.net.id
}

Penyebab kematian neonatal kelompok umur 0-7 hari adalah prematuritas dan berat badan lahir rendah/low birth weight (LBW) 35\%, diikuti oleh asfiksia lahir 33,6\%. Sedangkan penyebab kematian neonatal kelompok umur 8-28 hari adalah infeksi $57,1 \%$ (termasuk tetanus, sepsis, pnemonia, diare), dan masalah minum $14,3 \% .^{2}$

Infeksi neonatal dapat terjadi intrauterin melalui transplasental, didapat intrapartum saat melalui jalan lahir selama proses persalinan, atau pascapartum akibat sumber infeksi dari luar setelah lahir. Infeksi intrapartum dapat terjadi pada saat melalui jalan lahir atau infeksi asendens bila terjadi partus lama 
dan ketuban pecah dini. Kelompok virus yang sering menjadi penyebab termasuk herpes simplex, HIV, cytomegalovirus (CMV), dan hepatitis B yaitu virus yang jarang ditularkan secara transplasental. Sedangkan kelompok kuman termasuk Streptokokus grup B Gram negatif, kuman enterik Gram negatif (terutama Escheria coli), gonokokus dan klamidia. Infeksi pasca persalinan terjadi karena kontak dengan ibu yang terinfeksi secara langsung misalnya ibu yang mendrita tuberkulosis (meskipun dapat ditularkan intrauterin), melalui ASI (HIV, CMV), kontak dengan petugas kesehatan lain, atau kuman di lingkungan rumah sakit. ${ }^{3}$

Infeksi bakterial sistemik dapat terjadi kurang dari $1 \%$, penyakit virus $6 \%-8 \%$ dari seluruh populasi neonatus dan infeksi bakteri nosokomial 2\%-25\% dari bayi yang dirawat di NICU. Infeksi awitan dini apabila terjadi dalam lima hari pertama kehidupan pada umumnya disebabkan karena infeksi intrauterin atau intrapartum sedangkan infeksi awitan lambat terjadi sesudah umur tujuh hari dan sering terjadi selama pasca persalinan dan akibat kolonisasi nosokomial. ${ }^{4}$

Menurut perkiraan WHO, terjadi sekitar 5 juta kematian neonatus pada tahun 1995 dan menurun menjadi 4 juta pada tahun 2004, namun tetap 98\% terjadi di negara sedang berkembang. Sebagian infeksi dilaporkan di Korea terjadi akibat paparan dengan kuman dan sumber dari lingkungan pada saat pasca persalinan. ${ }^{5}$

\section{Infeksi akibat sindrom aspirasi mekonium}

Air ketuban keruh bercampur mekonium (AKK) dapat menyebabkan sindrom aspirasi mekonium (SAM) yang mengakibatkan asfiksia neonatorum yang selanjutnya dapat berkembang menjadi infeksi neonatal. Insidens air ketuban keruh terjadi pada 6\%-25\% kelahiran hidup, namun tidak semua neonatus yang mengalami AKK berkembang menjadi SAM. Neonatus dengan AKK 2\%-36\% menghirup mekonium sewaktu di dalam rahim atau saat napas pertama, sedangkan neonatus yang mempunyai AKK 11\% berkembang menjadi SAM dengan berbagai derajat. ${ }^{6}$

\section{Fisiologi dasar infeksi neonatal}

Sejak masa kehamilan sampai ketuban pecah, janin relatif terlindungi dari flora mikroba ibu oleh membran/dinding korioamniotik, plasenta, dan faktor antibakteria dalam air ketuban. Beberapa tindakan medis yang mengganggu integritas isi rahim seperti amniosintesis, cervical cerclage, pengambilan contoh vili korialis transservikal, atau pengambilan contoh darah perkutaneus, dapat memudahkan organisme normal kulit atau vagina masuk sehingga menyebabkan amnionitis dan infeksi sekunder pada janin. Bila ketuban pecah lebih dari 24 jam, bakteri vagina dapat bergerak naik dan pada beberapa kasus menyebabkan inflamasi pada membran janin, tali pusat, dan plasenta. Infeksi pada janin dapat disebabkan oleh aspirasi air ketuban yang terinfeksi, dapat mengakibatkan neonatus lahir mati, persalinan kurang bulan, atau sepsis neonatal. Organisme yang paling sering ditemukan dari air ketuban yang terinfeksi adalah bakteri anaerobik, streptokokus kelompok B, Eschericia coli, dan mikoplasma daerah genital. Infeksi pada ibu saat proses kelahiran terutama infeksi genital adalah jalur utama transmisi maternal dan dapat berperan penting pada kejadian infeksi neonatal. Infeksi hematogen transplasental selama atau segera sebelum persalinan (termasuk saat pelepasan plasenta) dapat terjadi walau infeksi lebih mungkin terjadi saat neonatus melewati jalan lahir. Banyak komplikasi penyakit dan gangguan kandungan yang terjadi sebelum dan sesudah proses persalinan yang berkaitan dengan peningkatan risiko infeksi pada neonatus baru lahir. Komplikasi ini meliputi persalinan kurang bulan, ketuban pecah dini yang berkepanjangan, inersia uterin dengan ekstraksi forseps tinggi, dan demam pada ibu. Saat bakteri mencapai aliran darah, sistem monosit-makrofag dapat menyingkirkan organisme tersebut secara efisien dengan opsonisasi oleh antibodi dan komplemen sehingga bakteriemi hanya terjadi singkat. Bakteremia tergantung dari usia pasien, virulensi dan jumlah bakteri dalam darah, status nutrisi dan imunologis, waktu dan asal intervensi terapi, menyebabkan respon inflamasi sistemik dari sumber infeksi berkembang luas. $^{7,8}$

\section{Sindrom aspirasi mekonium}

Air ketuban keruh terjadi pada 8\%-16\% dari seluruh persalinan, terjadi baik secara fisiologis ataupun patologis yang menunjukkan gawat janin. Faktor patologis yang berhubungan dengan AKK termasuk hipertensi maternal, penyakit kardiorespiratori 
maternal, eklampsia, dan berbagai sebab gawat janin. Keadaan AKK menempati posisi penting sebagai risiko SAM yang merupakan penyebab signifikan morbiditas dan mortalitas janin. ${ }^{9}$

Definisi SAM adalah sindrom atau kumpulan berbagai gejala klinis dan radiologis akibat janin atau neonatus menghirup atau mengaspirasi mekonium. Sindrom aspirasi mekonium dapat terjadi sebelum, selama, dan setelah proses persalinan. Mekonium yang terhirup dapat menutup sebagian atau seluruh jalan napas neonatus. Udara dapat melewati mekonium yang terperangkap dalam jalan napas neonatus saat inspirasi. Mekonium dapat juga terperangkap dalam jalan napas neonatus saat ekspirasi sehingga mengiritasi jalan napas dan menyebabkan kesulitan bernapas. Tingkat keparahan SAM tergantung dari jumlah mekonium yang terhirup, ditambah dengan kondisi lain seperti infeksi intrauterin atau lewat bulan (usia kehamilan lebih dari 42 minggu). Secara umum, semakin banyak mekonium yang terhirup, semakin berat kondisi klinis neonatus. Lingkaran kejadian yang terdiri dari hipoksemia, shunting atau pirau, asidosis, dan hipertensi pulmonal sering dihubungkan dengan SAM. Tujuan intervensi di kamar bersalin untuk menurunkan angka insidens dan tingkat keparahan aspirasi mekonium. Berdasar bukti dari penelitian yang tidak acak, direkomendasikan bahwa semua neonatus yang lahir dengan mekonium yang kental sebaiknya diintubasi sehingga dapat dilakukan penghisapan jalan napas dengan sempurna. Pada penelitian yang sedang berjalan, terjadi perdebatan pertimbangan penghisapan intratrakeal selektif atau pada semua neonatus dengan pewarnaan mekonium pada air ketuban. Artikel ini membahas bukti terbaru neonatus yang lahir dengan pewarnaan mekonium pada air ketuban dan kebutuhan intubasi untuk menghisap atau membersihkan jalan napas. ${ }^{10}$

Kejadian SAM merupakan masalah yang paling sering dihadapi spesialis anak dan spesialis kebidanan. Di Amerika Serikat diperkirakan 520.000 (12\% dari kelahiran hidup) dipersulit dengan adanya pewarnaan AKK dan 35\% diantaranya akan berkembang menjadi SAM (sekitar 4\% dari kelahiran hidup). Sekitar 30\% neonatus dengan SAM akan membutuhkan ventilasi mekanik, 10\% berkembang menjadi pneumotoraks, dan $4 \%$ meninggal. Enampuluh enam persen dari seluruh kasus hipertensi pulmonal persisten berkaitan dengan SAM. ${ }^{10}$ Pengeluaran mekonium ke dalam air ketuban pada umumnya merupakan akibat dari keadaan hipoksia intrauterin dan atau gawat janin. Apabila mekonium dikeluarkan dalam waktu empat jam sebelum persalinan, kulit neonatus akan berwarna mekonium. Neonatus yang lahir dengan letak sungsang atau presentasi bokong sering mengeluarkan mekonium sebelum persalinan namun tanpa terjadi gawat janin. ${ }^{11}$

Sekitar 1,3\% dari seluruh populasi bayi lahir hidup mempunyai komplikasi AKK dan hanya 5\% bayi baru lahir dengan AKK berkembang menjadi SAM. Yoder dkk yang dikutip oleh Gelfand SL dkk $^{12}$ mencatat adanya penurunan insidens SAM dari 5,8\% sampai 1,5\% terjadi selama periode 1990 sampai 1997 yang mendukung penurunan insidens kematian 33\% pada bayi dengan umur kehamilan lebih 41 minggu.

Mekonium di dalam AK dapat juga secara sederhana menunjukkan maturasi fungsi saluran cerna janin. Insidensi pasase mekonium jarang terjadi sebelum usia gestasi 34 minggu dan akan meningkatkan sampai usia kehamilan 37 minggu dan lebih meningkat lagi sesudah 37 minggu. $^{13}$

Derajat, penyebab, dan faktor risiko sindrom aspirasi mekonium

Kriteria derajat berat SAM dibedakan menjadi, SAM ringan apabila bayi memerlukan O2 kurang 40\% pada umur kurang 48 jam, SAM sedang apabila memerlukan lebih $40 \%$ pada umur lebih 48 jam tanpa kebocoran udara, dan SAM berat apabila memerlukan ventilator mekanik untuk lebih 48 jam dan sering dihubungkan dengan hipertensi pulmonal persisten. $^{12}$

Penyebab aspirasi mekonium mungkin terjadi intrauterin atau segera sesudah lahir. Hipoksia janin kronik dan asidosis dapat mengakibatkan gasping janin yang mempunyai konsekuensi aspirasi mekonium intrauterin. Beberapa bukti dilaporkan bahwa kejadian kronik intrauterin bertanggung jawab untuk kasus SAM berat yang berbeda dengan kejadian peripartum akut. Berbeda dengan, bayi yang lahir bugar yang menghirup AKK dari nasofaring pada saat lahir dapat berkembang menjadi SAM ringan sampai berat. ${ }^{12}$

Analisis bivariat menunjukkan empat faktor risiko terjadi SAM adalah skor Apgar $<5$ pada menit ke lima, mekonium kental, denyut jantung yang tidak teratur atau tidak jelas, dan berat lahir. ${ }^{14}$ Mekonium kental merupakan faktor penyebab kematian yang penting, kurang lebih sepertiga bayi dengan SAM memerlukan ventilator mekanik $13,3 \% .^{15}$ 


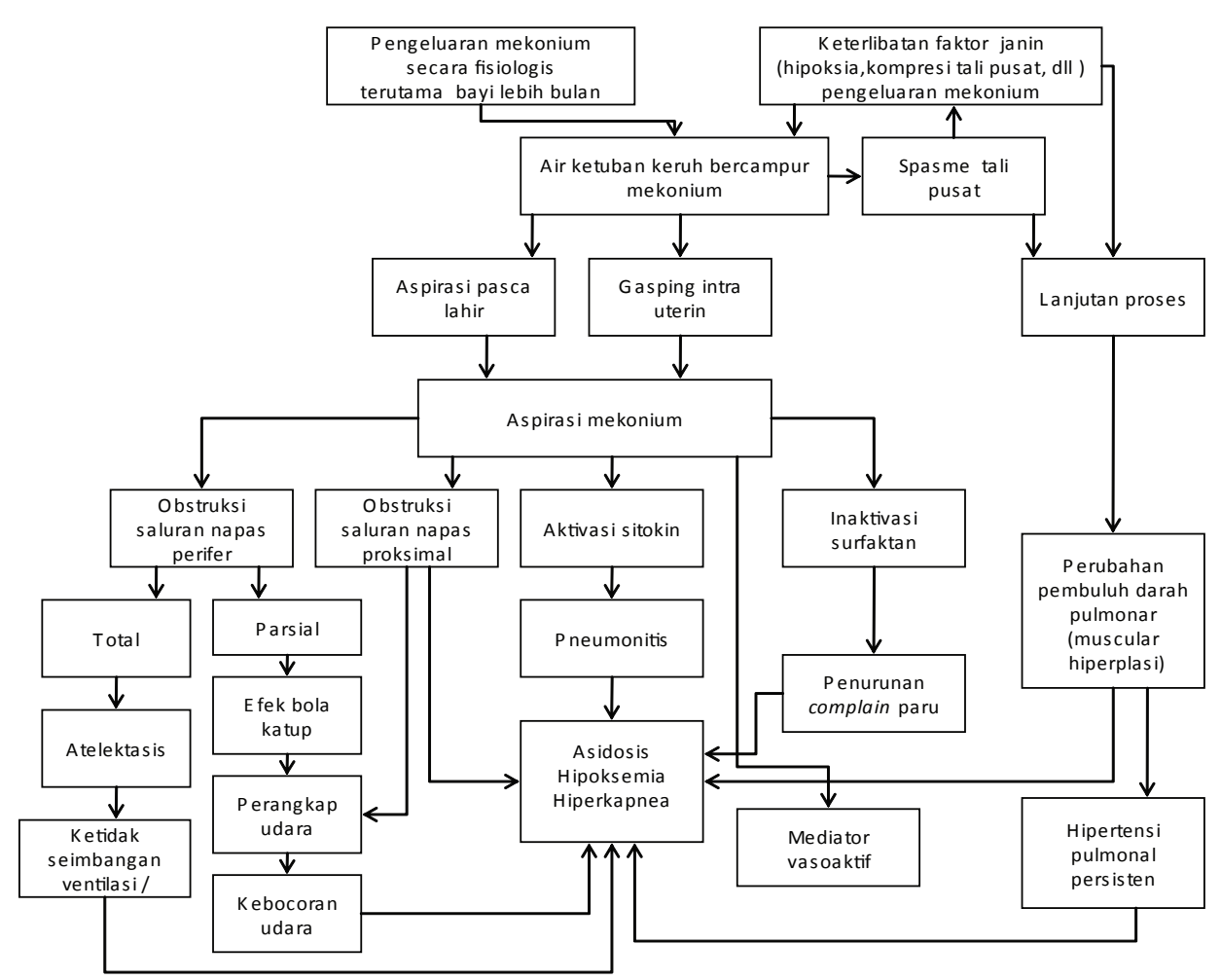

Gambar 1: Mekanisme patofisiologi SAM. ${ }^{13}$

\section{Mekanisme terjadinya sindrom aspirasi mekonium}

Mekonium diduga sangat toksik bagi paru karena berbagai macam cara. Sulit menentukan mekanisme mana yang paling dominan dalam suatu saat. Mekanisme terjadinya SAM diduga melalui mekanisme, obstruksi mekanik saluran napas, pneumonitis kimiawi, vasokonstriksi pembuluh darah vena, dan surfaktan yang inaktif. ${ }^{12}$

\section{Obstruksi mekanik}

Mekonium yang kental dan liat dapat menyebabkan obstruksi mekanik total atau parsial. Pada saat bayi mulai bernapas, mekonium bergerak dari saluran napas sentral ke perifer. Partikel mekonium yang terhirup ke dalam saluran napas bagian distal menyebabkan obstruksi dan atelektasis sehingga terjadi area yang tidak terjadi ventilasi dan perfusi menyebabkan hipoksemia. Obstruksi parsial menghasilkan dampak katup-bola atau ballvalve effect yaitu udara yang dihirup dapat memasuki alveoli tetapi tidak dapat keluar dari alveoli. Hal ini akan mengakibatkan air trapping di alveoli dengan gangguan ventilasi dan perfusi yang dapat mengakibatkan sindrom kebocoran udara dan hiperekspansi. Risiko terjadinya pneumotoraks sekitar $15 \%-33 \% .{ }^{12}$

\section{Pneumonitis}

Mekonium diduga mempunyai dampak toksik secara langsung yang diperantarai oleh proses inflamasi. Dalam beberapa jam neutrofil dan makrofag telah berada di dalam alveoli, saluran napas besar dan parenkim paru. Dari makrofag akan dikeluarkan sitokin seperti TNF $\alpha$, TNF-1 $\beta$, dan interleukin-8 yang dapat langsung menyebabkan gangguan pada parenkim paru atau menyebabkan kebocoran vaskular yang mengakibatkan pneumonitis toksik dengan perdarahan paru dan edema. Mekonium mengandung berbagai zat seperti asam empedu yang apabila dijumpai dalam air ketuban akan menyebabkan kerusakan langsung pembuluh darah tali pusat dan kulit ketuban, serta mempunyai dampak langsung vasokonstriksi pada pembuluh darah umbilical dan plasenta. ${ }^{12}$

\section{Vasokonstruksi pulmonal}

Kejadian SAM berat dapat menyebabkan komplikasi 
hipertensi pulmonal persisten. Pelepasan mediator vasoaktif seperti eikosanoids, endotelin-1, dan prostaglandin E2 (PGE2), sebagai akibat adanya mekonium dalam air ketuban diduga mempunyai peran dalam terjadinya hipertensi pulmonal persisten. ${ }^{12}$

\section{Diagnosis sindrom aspirasi mekonium}

Sindrom aspirasi mekonium harus dipertimbangkan terjadi pada setiap bayi baru lahir dengan AKK yang mengalami gejala gangguan napas atau distres respirasi.

Gambaran pemeriksaan radiologi klasik menunjukkan sebaran infiltrat difus dan asimetris. Berhubung berbagai mekanisme yang menyebabkan SAM maka temuan gambaran radiologikpun bervariasi. Seringkali dijumpai overaerasi yang dapat menyebabkan sindrom kebocoran udara seperti pneumotoraks, pneumomediastinum, atau emfisema pulmonum intersisialis. Terdapat hubungan antara derajat kelainan abnormalitas radiologik dan derajat penyakit SAM dengan konsolidasi atau atelektasis yang merupakan faktor prognosis yang kurang baik. Meskipun ada penelitian lain yang tidak mengkonfirmasi hubungan ini.

Pasien dengan gambaran radiologi klasik menunjukkan perbaikan lambat setelah beberapa hari sampai beberapa minggu. Pemeriksaan ekokardiografi dua dimensi diperlukan untuk mengevaluasi hipertensi pulmonal dan berguna untuk bayi pada awal kehidupannya. ${ }^{12}$ Kejadian AKK merupakan tanda yang serius pada janin yang dihubungkan dengan kenaikan morbiditas perinatal, maka monitor denyut janin merupakan indikator penting. Dipertimbangkan keadaan kontroversial yang ada saat ini, berhubungan dengan sebab pasase mekonium intra uterin. Di dalam rahim hipoksia mengakibatkan relaksasi otot sfingter ani dipertimbangkan sebagai penyebab pasase mekonium. Sebaliknya lingkungan intra uterin akan mempengaruhi kesejahteraan janin dan mengakibatkan AKK misalnya infeksi intra uterin yang mengakibatkan korioamnionitis, perlu diingat AK merupakan media kultur yang kurang baik untuk kuman. Air ketuban yang terinfeksi dan ditelan janin akan memicu terjadinya defekasi dini oleh janin yang juga dapat diterangkan sebagai penyebab AKK. ${ }^{16}$

\section{Diagnosis infeksi neonatal}

Diagnosis infeksi neonatal didasarkan atas anamnesis, pemeriksaan klinis, dan pemeriksaan penunjang (laboratorium). Salah satu panduan yang digunakan untuk mendiagnosis infeksi neonatal bahkan yang berlanjut menjadi sepsis tertera pada Tabel 1 .

\section{Diagnosis laboratorium}

a. Diagnosis pasti infeksi neonatal ditegakkan berdasarkan biakan darah, cairan serebrospinal, urin, dan infeksi lokal

b. Diagnosis tidak langsung:

- Jumlah leukosit, hitung jenis, leukopenia $<5000 / \mathrm{mm} 3$, leukositosis $>12000 / \mathrm{mm} 3$, hanya bernilai untuk sepsis awitan lambat

- Neutropenia (<1500/mm3), neutrofilia

Tabel 1. Manifestasi klinis infeksi neonatal

\begin{tabular}{ll}
\hline Kategori A & Kategori B \\
\hline - Kesulitan bernapas (misalnya, apnea, napas lebih dari 30 & $\bullet$ Tremor \\
kali per menit, retraksi dinding dada, grunting pada waktu & - Letargi atau lunglai \\
ekspirasi, sianosis sentral) & - Mengantuk atau aktivitas berkurang \\
- Kejang & $\bullet$ Iritabel atau rewel \\
- Tidak sadar & Muntah (menyokong kecurigaan sepsis) \\
- Suhu tubuh tidak normal (tidak normal sejak lahir dan & $\bullet$ Perut kembung (menyokong kecurigaan sepsis) \\
tidak memberi respons terhadap terapi atau suhu tidak stabil & Tanda klinis mulai tampak sesudah hari ke empat \\
sesudah pengukuran suhu normal selama tiga kali atau lebih, & (menyokong kecurigaan sepsis) \\
menyokong diagnosis sepsis) & Air ketuban bercampur mekonium \\
- Persalinan di lingkungan yang kurang higienis (menyokong & Malas minum sebelumnya minum dengan baik \\
kecurigaan sepsis) & (menyokong kecurigaan sepsis) \\
Kondisi memburuk secara cepat dan dramatis (menyokong & \\
kecurigaan sepsis) & \\
\hline
\end{tabular}

Sumber : Kosim MS dkk ${ }^{17}$ 
(<7000/mm3) hanya bernilai untuk sepsis awitan lambat

- $\quad$ Rasio I:T ( >0,18)

- Trombositopenia $(<100,000 / \mathrm{mm} 3)$

- $C$-reactive protein positif (>6 mg/L), merupakan nilai prognostik

- ESR (erytrocyte sedimentation rate) atau microESR pada dua minggu pertama (nilai normal dihitung pada usia hari ketiga)

- Haptoglobin, fibrinogen dan leukocyte elastase assay.

- Pengecatan gram cairan aspirat lambung positif (bila $>5$ neutrophils/LPB) atau ditemukan bakteri

- Pemeriksaan fibonektin

- Pemeriksaan sitokin, interleukin-1, soluble interleukin 2receptor, interleukin-6, dan tumour necrosis factor $-\alpha$, dan deteksi kuman patogen GBS \& ECK 1 dengan, pemeriksaan latex particle agglutination dan countercurrent immunoelectrophoresis.

- Polymerase chain reaction suatu cara baru untuk mendeteksi DNA bakteri.

- Prokalsitonin merupakan petanda infeksi neonatal awitan dini dan lambat, memberikan hasil yang cukup baik pada kelompok risiko tinggi. ${ }^{18}$

- Pada neonatus yang sakit berat, kadar prokalsitonin merupakan petanda infeksi yang lebih baik dibanding $C$-reactive protein dan jumlah leukosit. Kadar prokalsitonin $2 \mathrm{mg} / \mathrm{ml}$ mungkin sangat berguna untuk membedakan penyakit infeksi bakterial dari virus pada neonatus dan anak. ${ }^{19}$

Disimpulkan bahwa petanda infeksi atau sepsis neonatal dilakukan melalui pengukuran serial petanda infeksi untuk meningkatkan sensitivitas diagnosis dan berguna untuk penghentian secara dini terapi antibiotik. Namun tidak ada satupun uji diagnosis terbaru yang cukup sensitif dan spesifik untuk mempengaruhi keputusan klinis dan meneruskan terapi antibiotik pada saat awitan dugaan infeksi. ${ }^{18,20,21}$

Oleh karena itu suatu petanda diagnostik yang kompeten juga harus mempunyai spesifisitas yang tinggi (hasil negatif bila tidak ada infeksi) dan nilai prediksi positif yang baik (ada infeksi bila hasil positif) yang sebaiknya lebih dari $85 \%$, dalam rangka untuk mengurangi penggunaan antibiotik yang tidak perlu pada kasus positif palsu. Sebagai tambahan nilai potong yang optimal harus ditentukan pada populasi pasien secara spesifik dengan menggunakan kurva ROC (receiver operating characteristics curve) untuk setiap petanda. ${ }^{20}$

\section{Daftar Pustaka}

1. Indonesia on line. Angka kematian bayi masih tinggi. Didapat dari: http://www.indonesiaontime.com/humanioral kesehatan/19-kesehatan/4100--angka-kematian-bayi-masihtinggi-.html

2. Djaja S. Penyakit penyebab kematian bayi baru lahir (neonatal) dan sistem pelayanan kesehatan yang berkaitan di Indonesia. Didapat dari: http:/ldigilib.litbang. depkes.go.id/go.php?id=jkpkbppk-gdl-res-2003-sarimawar-881neonatalo $q=$ survei.

3. Merck Manual Professional. Infections in neonates. Didapat dari: http://www.merck.com/mmpe/sec19/ch279/ ch279a.html.

4. Adam D. Infection in neonates and prematures. Phil J Microbiol Infect Dis 1992; 22(3):332-45.

5. Hye Sun Yoon, Youn Jeong Shin, Moran Ki. Risk Factors for neonatal infections in full-term babies in South Korea Yonsei Med J 2008;49:530-6.

6. Homeier BP, Spear ML. Meconium aspiration. Didapat dari: http://kidshealth.org/parent/medical/lungs/meconium. html.

7. Chiesa C, Alessandra PA, Osborn JF, Simonetti AF, Pacifico1 L. Diagnosis of neonatal sepsis: a clinical and laboratory challenge. Clin Chem 20074;50: 279-287.

8. New Newborn Clinical Guideline- Meconium-stained liquor and MAS. Didapat dari: http://www.adhd.govt.nz/ newborn/Guidelines/Admission/Meconium

9. David A N, Njokanma OF, Iroha E. Incidence of and factors associated with meconium staining of the amniotic fluid in a Nigerian University teaching hospital. J Obstet Gynaecol 2006;26:518-20.

10. Thakre R. Meconium stained amniotic fluid delivery. to intubate or not? Didapat dari: http://www.neoclinic.net/ Artcl/msaf.htm.

11. Klein JM. Care of the infant with the meconium aspiration syndrome. Dalam: Iowa Neonatology Handbook: pulmonary. Didapat dari: http://www. uihealthcare.com/depts/med/pediatrics/iowaneonatolog

12. Gelfand SL, Jonathan M, Fanaroff JM, Walsh MC. Meconium stained fluid: approach to themother and the baby. Pediatr Clin N Am 2004; 51:655- 67. 
13. Klingner MC, Jerry Kruse J. Meconium Aspiration Syndrome: Pathophysiology and Prevention. Diunduh dari URL : http://www.medscape.com/viewarticle/437101

14. Khazardoost1 S, Hantoushzadeh S, Khooshideh M, Borna1 S. Risk factors for meconium aspiration in meconium stained amniotic fluid. J Obstet Gynaecol 2007;27:577-9.

15. Bhat RY, Rao D. Meconium-stained amniotic fluid and meconium aspiration syndrome: a prospective study. Ann of Trop Paediatr 2008;28: 199-203.

16. Rao S, Pavlova Z, Incerpi MH Ramanathan R. Meconium-stained amniotic fluid and neonatal morbidity in near-term and term deliveries with acute histologic, chorioamnionitis and/or funisitis. J Perinatol 2001;21:537-40.

17. Kosim MS, Indarso F, Sarosa GI, Hendarto TW. Komponen neonatal. Dalam: Buku acuan pelatihan pelayanan obstetri neonatal emergensi dasar. Jakarta: Departemen Kesehatan RI, bekerjasama dengan Perkumpulan Obstetri dan
Ginekologi Indonesia, Jaringan Nasional Kesehatan Reproduksi. Ikatan Dokter Anak Indonesia; Departemen Kesehatan Republik Indonesia, Maternal and Neonatal Health JHPIEGO; 2005.h. 92-7.

18. Chiesa C, Panero A, Rossi N. Stegagno M, De Giusti M, Osborn JF, dkk. Reliability of procalcitonin concentrations for the diagnosis of sepsis in critically Ill neonates. CID 1998;26.

19. Mark H, Shane MT, Kim S, Charles T, Ian AM. Diagnostic markers of infection: comparison of procalcitonin with $\mathrm{C}$ reactive protein and leucocyte count. Arch Dis Child 1999;81:417-21.

20. P C Ng. Diagnostic markers of infection in neonates. Arch Dis Child Fetal Neonatal 2004;89:229-35.

21. Yi-Ling Chan, Ching-Ping Tseng, Pei-Kuei Tsay, ShyShin Chang, Te-Fa Chiu, Jih-Chang Chen. Procalcitonin as a marker of bacterial infection in the emergency department: an observational study. Critical Care; 2004: R12-20. 